\title{
Elevated level of inhibin- $\alpha$ subunit is pro-tumourigenic and pro-metastatic and associated with extracapsular spread in advanced prostate cancer
}

\section{P Balanathan ${ }^{*, 1}$, ED Williams², H Wang', JS Pedersen ${ }^{3}$, LG Horvath ${ }^{4,5}$, MG Achen ${ }^{6}$, SA Stacker ${ }^{6}$ and GP Risbridger'}

'Centre for Urological Research, Monash Institute of Medical Research, Monash University, Melbourne, Victoria 3168, Australia; ${ }^{2}$ Centre for Cancer Research, Monash Institute of Medical Research, Monash University, Melbourne, Victoria 3168, Australia; ${ }^{3}$ Tissupath Pty Ltd, 165 Burwood Road, Melbourne, Victoria 3122, Australia; ${ }^{4}$ Sydney Cancer Centre, Missenden Road, Sydney, New South Wales 2050, Australia; ${ }^{5}$ Cancer Research Program, Garvan Institute of Medical Research, 384 Victoria Street, Sydney, New South Wales 20 I0, Australia; ${ }^{6}$ Ludwig Institute for Cancer Research, Royal Melbourne Hospital, Post Office Box 2008, Parkville, Victoria 3050, Australia

The biological function of inhibin- $\alpha$ subunit $(\mathrm{INH} \alpha)$ in prostate cancer (PCa) is currently unclear. A recent study associated elevated levels of $\mathrm{INH} \alpha$ in PCa patients with a higher risk of recurrence. This prompted us to use clinical specimens and functional studies to investigate the pro-tumourigenic and pro-metastatic function of $\mathrm{INH} \alpha$. We conducted a cross-sectional study to determine a link between INH $\alpha$ expression and a number of clinicopathological parameters including Gleason score, surgical margin, extracapsular spread, lymph node status and vascular endothelial growth factor receptor-3 expression, which are well-established prognostic factors of PCa. In addition, using two human PCa cell lines (LNCaP and PC3) representing androgen-dependent and -independent $\mathrm{PC}$ a respectively, we investigated the biological function of elevated levels of $\mathrm{INH} \alpha$ in advanced cancer. Elevated expression of $\mathrm{INH} \alpha$ in primary PCa tissues showed a higher risk of PCa patients being positive for clinicopathological parameters outlined above. Overexpressing $\mathrm{INH} \alpha$ in LNCaP and PC3 cells demonstrated two different and cell-type-specific responses. INH $\alpha$-positive LNCaP demonstrated reduced tumour growth whereas INH $\alpha$-positive PC3 cells demonstrated increased tumour growth and metastasis through the process of lymphangiogenesis. This study is the first to demonstrate a pro-tumourigenic and pro-metastatic function for $\mathrm{INH} \alpha$ associated with androgen-independent stage of metastatic prostate disease. Our results also suggest that INH $\alpha$ expression in the primary prostate tumour can be used as a predictive factor for prognosis of PCa.

British Journal of Cancer (2009) I 00, 1784-1793. doi:I0.1038/sj.bjc.6605089 www.bjcancer.com

Published online 12 May 2009

(c) 2009 Cancer Research UK

Keywords: inhibin- $\alpha$ subunit; prostate cancer; metastasis; androgen independent

Inhibins $\mathrm{A}$ and $\mathrm{B}$ are members of the transforming growth factor- $\beta$ (TGF $\beta)$ superfamily. Inhibins are heterodimers of an $18 \mathrm{kDa}$ $\alpha$-subunit disulphide linked to one of two $13 \mathrm{kDa} \beta$-subunits $(\beta \mathrm{A}$ and $\beta \mathrm{B})$ resulting in inhibin $\mathrm{A}(\alpha \beta \mathrm{A})$ and $\mathrm{B}(\alpha \beta \mathrm{B})$ respectively. Primarily of gonadal origin, inhibins regulate pituitary folliclestimulating hormone secretion by feedback inhibition. In humans, women produce both inhibin A and inhibin B (Welt et al, 1999; Welt and Schneyer, 2001), whereas in adult men inhibin B is the primary form (Marchetti et al, 2003). Inhibins have also been shown to be expressed in adrenal cortex, pituitary and prostate (reviewed in Risbridger et al, 2001). Other endocrine and paracrine functions of inhibins involve regulating members of the TGF $\beta$ superfamily, such as TGF $\beta$ itself, activins and bone morphogenic protein (BMP), by competing for their receptors (Wiater and Vale, 2003; Farnworth et al, 2007). This antagonistic effect of inhibin is

*Correspondence: Dr P Balanathan;

E-mail: preetika.balanathan@med.monash.edu.au

Received 5 January 2009; revised 30 March 2009; accepted 6 April 2009; published online 12 May 2009 amplified in the presence of the inhibin receptor, TGF $\beta$ receptor III (TGF $\beta$ RIII), also known as betaglycan.

The first study that linked inhibin to reproductive cancers showed that serum inhibin increased in women with granulosa cell tumours of the ovary (Lappohn et al, 1989) and inhibin currently serves as a robust biomarker for this cancer. A direct biological function for inhibin in carcinogenesis was demonstrated by Matzuk et al (1992) when they created the inhibin- $\alpha$ subunit $(\mathrm{INH} \alpha)$ knockout mouse. Both sexes developed gonadal sex-cord stromal tumours with high penetrance and developed tumours in their adrenal glands after castration, showing that $\mathrm{INH} \alpha$ can act as a tumour suppressor. Subsequent mouse model studies revealed a complex network of interactions involving inhibin, activin and other modifiers in the development and progression of gonadal and adrenal tumours in INH $\alpha$-deficient mice (reviewed in Risbridger et al, 2001). Although it is clear that total inhibin as a serum test has utility in the initial detection and prognosis of certain types of ovarian cancers, the biological function of inhibin in tumourigenesis is far from clear.

We have observed both up- and down-regulation of $\mathrm{INH} \alpha$ expression in prostate cancer (PCa) tissues dependent on the stage 
of disease. Studies from our laboratory on metastatic PCa epithelial cell lines demonstrated that high concentrations $\left(400 \mathrm{ng} \mathrm{ml}^{-1}\right)$ of recombinant inhibin A inhibited growth of androgen-responsive LNCaP cells, but not androgen-independent DU145 cells, suggesting that the effect of inhibin may be dependent on cell phenotypes related to specific stages of PCa (McPherson et al, 1997). Furthermore, we have shown loss of heterozygosity or epigenetically regulated loss or down-regulation of INH $\alpha$ in PCa patient samples and LNCaP, DU145 and PC3 cell lines (Mellor et al, 1998; Schmitt et al, 2002; Balanathan et al, 2004). Collectively, these data suggest a tumour suppressive function for $\mathrm{INH} \alpha$ in the prostate. In contrast, new insights into the role of INH $\alpha$ in the prostate came from a recent study using a large cohort of PCa patient tissues that showed that $\mathrm{INH} \alpha$ was frequently over-expressed in high-grade $\mathrm{PCa}$ (Risbridger et al, 2004a, b). The intensity of $\mathrm{INH} \alpha$ immunoreactivity was associated with a higher risk of recurrence of PCa. These variable clinical and experimental observations provide equivocal evidence for a role of INH $\alpha$ in $\mathrm{PCa}$. Thus it was proposed that like TGF $\beta$ (Roberts and Wakefield, 2003), INH $\alpha$ has tumour suppressive activity in normal epithelial cells, which changes to tumour promoting in cancer cells (Ball et al, 2004; Risbridger et al, 2004a).

To date there is no proof that $\mathrm{INH} \alpha$ can increase tumourigenesis and metastasis. Thus the primary aim of this study was to examine the pro-tumourigenic and pro-metastatic function of $\mathrm{INH} \alpha$ in advanced PCa. Specifically, the expression profile of INH $\alpha$ and clinicopathological parameters were examined in primary $\mathrm{PCa}$ tissues including specimens from patients with organ-confined disease and those with metastasis to the lymph nodes. In addition, human metastatic PCa cell lines, LNCaP and PC3, were used in in vitro and in vivo functional studies to determine the biological function of elevated levels of INH $\alpha$ on migration, invasion, tumour growth and metastasis.

\section{MATERIALS AND METHODS}

\section{Analysis of clinical material}

Relationship between INH $\alpha$ expression and clinicopathological parameters in primary prostate adenocarcinomas This study was conducted in accordance with Australian National Health and Medical Research Council (NHMRC) guidelines. Archival formalin-fixed paraffin-embedded tissue blocks were retrieved from 37 patients with prostate carcinoma who underwent radical prostatectomy. The clinicopathological characteristics, vascular endothelial growth factor-C (VEGF-C) expression, lymphatic vessel density (LVD) and lymph node status of this cohort have been described previously (Zeng et al, 2004, 2005). We conducted a cross-sectional study to determine whether INH $\alpha$ expression was associated with clinicopathological parameters (Gleason score, surgical margins, extracapsular spread, VEGF receptor-3 (VEGFR-3) expression and lymph nodes status) and/or linked to well-established prognostic factors in prostatic adenocarcinoma. The PO 12 antibody (kindly provided by Dr Nigel Groome) was used to determine the expression pattern of $\mathrm{INH} \alpha$ in primary prostate tissues as previously described (Risbridger et al, 2004b). Each immunostained tissue section was assessed and staining intensity in benign epithelial, cancer (Gleason grade G3/G4) and stromal regions was scored from 0 to 4 with 0 representing negative staining and 4 representing very strong positive staining. The relative risk of PCa patients being positive for the respective parameters was determined.

Stable transfection of LNCaP and PC3 cell lines LNCaP and PC3 were obtained from American Type Culture Collection (Rockville, $\mathrm{MD}$, USA) and routinely cultured as described previously (Balanathan et al, 2004). Expression vectors pcDNA3.1 (empty vector, EV) and human INH $\alpha$ cDNA subcloned into pcDNA3.1
(pcDNA3.1 $(\mathrm{INH} \alpha)$ ) were purchased from Invitrogen (Mount Waverley, Victoria, Australia) and prepared for transfection according to the manufacturer's instructions. LNCaP and PC3 cells were transfected using Lipofectamine plus (Invitrogen) and Superfect (Qiagen, Doncaster, Victoria, Australia) respectively according to the manufacturer's instructions. Individual colonies surviving after 2-3 weeks selection were picked and propagated for analysis.

Confirmation of mRNA expression in INH $\alpha$-transfected LNCaP and PC3 cell lines Total RNA was extracted using RNeasy Mini Kit (Qiagen) according to the manufacturer's instructions. Reverse transcription (RT) was performed as previously described (Balanathan et al, 2004). $\beta_{2}$-microglobulin $\left(\beta_{2} m g\right)$ was used as a housekeeping gene for block PCR. Primer sequences were: INHA, forward: CCTGTTCTTGGATGCCTTG; reverse: AGCTGGGCTGAA GTCACCT and $\beta_{2} \mathrm{mg}$, forward: CCGTGTGAACCATGTGACTT; reverse: CAAACATGGAGACAGCACTC. Absolute quantitative real-time analysis was used to assess the levels of TGF $\beta$ RIII mRNA expression in the clones. The analysis was performed on a LightCycler real-time PCR machine (Roche Diagnostic, Mannheim, Germany) using LightCycler Fast Start DNA Master SYBR Green 1 (Roche Diagnostic) according to the manufacturer's instructions. All experiments were carried out twice and duplicate readings were taken for each replicate. The quantity of mRNA was determined using a standard curve and all values were normalised using the housekeeping gene, hypoxanthine ribosyl transferase (HPRT). Primer sequences were: TGF $\beta$ RIII, forward: TTCCCTGTTCACCC GACCTGAAAT; reverse: CGTCAGGAGGCACACATTA and HPRT, forward: TGTAATGACCAGTCAACAGGG; reverse: TGGCTTATAT CCAACACTTCG.

Confirmation of protein expression by ELISA Cell lysates and conditioned media (conditioned for $24 \mathrm{~h}$ ) were prepared from EV- and INH $\alpha$-transfected clones. Total protein $\left(1 \mu \mathrm{g} \mu \mathrm{l}^{-1}\right)$ was used for further analysis. Inhibin $A$ and $B$ and activin A concentrations were measured in triplicate using specific ELISA according to the manufacturer's instructions (Diagnostic Systems Laboratories, Webster, TX, USA). VEGF-A and VEGF-C ELISAs were measured in duplicate using specific ELISA according to the manufacturer's instructions (R\&D Systems, Minneapolis, MN, USA). Two biological replicates were examined.

Direct cell counting: proliferation assay $\mathrm{LNCaP}$ and PC3 cells were seeded at a density of $1 \times 10^{5}$ cells per well and $5 \times 10^{3}$ cells per well, respectively, in 24-well plates and incubated at $37^{\circ} \mathrm{C}$. Triplicate wells were harvested by trypsinisation on days $1,2,3,4$ and 5, and numbers of cells per well were counted using haemocytometer. Each experiment was repeated twice. The results obtained from individual clones (EV and $\mathrm{INH} \alpha$ ) were pooled for each treatment.

Scratch wound assay: motility assay Cells were plated in triplicate in 6- or 12-well plates and grown until approximately $70-80 \%$ confluence. The cell monolayer was then wounded and analysed over time as previously described (Sharp et al, 2004). Each experiment was repeated twice. The results obtained from individual clones (EV and $\mathrm{INH} \alpha$ ) were pooled for each treatment.

Intra-prostatic inoculation of LNCaP and PC3 cells The experiments were in accordance with NHMRC of Australia guidelines. LNCaP $\left(2 \times 10^{6}\right)$ or PC3 $\left(5 \times 10^{5}\right)$ clones were injected orthotopically into the ventral lobe of the prostate gland (10 animals per clone) of male SCID mice as previously described (Zeng et al, 2006). After 7-9 weeks, mice were killed and primary prostate tumours were removed and weighed. In addition, regional lymph nodes were removed for analysis. Monoclonal human mitochondria antibody ( $1: 100$; Chemicon, Temecula, CA, USA) was used to 
determine the presence of human cells in the tumours as previously described (McCulloch et al, 2005). The monoclonal R1 antibody $\left(7.5 \mu \mathrm{g} \mathrm{ml}^{-1}\right)$, kindly provided by Dr Nigel Groome, was used to determine INH $\alpha$ expression in tumours as previously described (Balanathan et al, 2004).

Lymph node volumes were determined using stereological analysis as previously described (McPherson et al, 2001). The lymph nodes were serially sectioned at $5 \mu \mathrm{m}$ thickness and using a random sampling scheme, every 20th section was chosen for analysis. Briefly, the computer program newCAST component (version 2.14; Visiopharm, Hørsholm, Denmark) was used to generate a point grid, and volumes of the lymph nodes were determined. Each section was examined using $\times 20$ magnification and tissue sections were mapped to define tissue boundaries and were sampled at predetermined intervals along $x$ - and $y$-axes using a single grid-counting frame. The volume was then determined using the equation $=$ no of points for each tissue $\times$ area per point $\times$ distance; in this case the distance was defined by thickness of the sections $(5 \mu \mathrm{m})$ plus $(5 \mu \mathrm{m} \times 20$ for every 20 th section $)$.

LVD in the intra-prostatic tumours Lymphatic vessels were identified using lymphatic vascular endothelial hyaluronan receptor (LYVE-1), a marker of lymphatic endothelium (Banerji et al, 1999). Invasion of tumour cells into lymphatics was monitored by the presence of human mitochondrial protein-stained cancer cells in lymph vessels. Double immunostaining for LYVE-1 and mitochondria was performed on a Dako Autostainer (Dako, Glostrup, Denmark). The sections were incubated with LYVE-1 antibody (Fitzgerald, Boston, MA, USA) diluted at $0.5 \mu \mathrm{g} \mathrm{ml}^{-1}$ for $2 \mathrm{~h}$. LYVE-1 was detected by incubation with Envision polymeranti-rabbit-HRP (Dako) for $15 \mathrm{~min}$ and visualised with diaminobenzidine (Dako). Sections were then incubated with Double Staining Enhancer (Zymed, San Francisco, CA, USA) for 15 min and exposed to mitochondrial antibody (Chemicon) diluted at $1: 200$ for $2 \mathrm{~h}$. Secondary antibody, biotinylated rabbit anti-mouse IgG1 (Zymed) was applied and the immunoreactivity was detected by ExtrAvidin-Alkaline phosphatase (Sigma, St Louis, MO, USA) and visualised by reaction with Vector Red (Vector Laboratories, Burlingame, CA, USA). The sections were counterstained with hematoxylin (Dako) and immunolocalisation was examined using an Olympus BX-60 microscope (Tokyo, Japan).

Lymphatic vessels were counted using stereological methods as previously described (Balanathan et al, 2004). Lymphatic vessels were counted within tissue sections (of randomly selected INHApositive prostate tumours, $n=15$ and EV tumours, $n=11$; using $n=2$ randomly selected sections per tumour) to assess the LVD within the tumour (intra-tumoural) region, the region in contact with both the tumour and the stroma (peritumoural) and the region away from tumour. LVD was expressed as the number of lymph vessels per $\mathrm{mm}^{2}$.

Statistical analyses All statistical analyses were performed and results were analysed by ANOVA or $t$-tests as specified. The relationships between INH $\alpha$ expression and clinicopathological parameters were evaluated by Fisher's exact test. The mean staining intensity of patients positive for each of the respective clinicopathological parameter was compared to the mean staining intensity (reference) of those patients who were negative. The relative risks and $95 \%$ confidence intervals (CI) were estimated.

\section{RESULTS}

\section{Relationship between INH $\alpha$ expression and clinicopathological parameters in primary prostate adenocarcinomas}

Immunostaining revealed differential expression of $\mathrm{INH} \alpha$ in benign epithelial, G3/G4 cancer regions as well as in the stroma of primary $\mathrm{PCa}$ tissues from patients with organ-confined disease (Figure 1A-D) and those with metastasis to the lymph nodes (Figure 1E-H). Association between clinicopathological prognostic factors and $\mathrm{INH} \alpha$ expression is shown in Table 1. Elevated expression of INH $\alpha$ in the benign epithelial regions of the primary $\mathrm{PCa}$ tissues showed a higher relative risk in $\mathrm{PCa}$ patients positive for extracapsular spread $(P=0.01)$. Similarly, elevated expression of INH $\alpha$ in the stroma of the primary PCa tissues showed a higher risk of PCa patients positive for extracapsular spread $(P=0.0011)$, surgical margins $(P=0.0006)$, VEGFR-3 expression $(P=0.00067)$ and lymph node metastasis $(P<0.0001)$. Further analysis showed that there was a significant increase in $\mathrm{INH} \alpha$ staining in benign epithelial $(P=0.018)$ and stromal $(P<0.0001)$ regions but not in G3/G4 cancer regions in tissues from patients with lymph node metastasis compared to patients with organ-confined disease (data not shown).

\section{Isolation and characterisation of cells over-expressing INH $\alpha$}

The INH $\alpha$ expression profile in clinical specimens suggests protumourigenic and pro-metastatic function for INH $\alpha$ in advanced
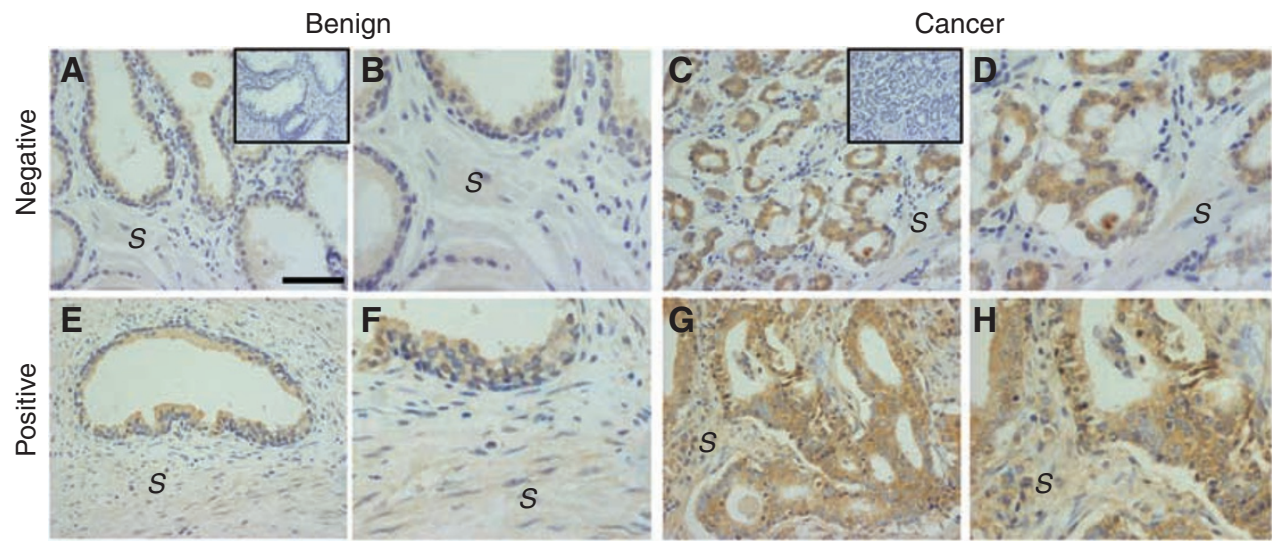

Figure I $\mathbb{N H H} \alpha$ expression in clinical specimens and its association to prostate disease. Immunohistochemical staining of INH $\alpha$ in primary prostate tumours from PCa patients with $(\mathbf{A}-\mathbf{D})$ organ-confined (negative) and $(\mathbf{E}-\mathbf{H})$ metastatic disease (positive). INH $\alpha$ immunostaining intensity in benign epithelial, cancer region (G3/G4) and stromal regions (S) is shown. Inset shows lgG control. Bar $=200 \mu \mathrm{m}$. B, D, F and $\mathbf{H}$ are enlargements of $\mathbf{A}, \mathbf{C}, \mathbf{E}$ and G, respectively. 
Table I Relationships between the expression of $\mathrm{INH} \alpha$ and clinicopathological parameters in prostate adenocarcinoma $(n=37)$

\begin{tabular}{|c|c|c|c|c|c|c|c|c|c|c|}
\hline \multirow[b]{2}{*}{ Parameters } & \multirow[b]{2}{*}{$\begin{array}{c}\text { No. of } \\
\text { specimens }\end{array}$} & \multicolumn{3}{|c|}{ Benign regions } & \multicolumn{3}{|c|}{ Cancer regions (G3/G4) } & \multicolumn{3}{|c|}{ Stromal regions } \\
\hline & & $\begin{array}{c}\text { Mean } \\
\text { intensity }\end{array}$ & $\begin{array}{l}\text { Relative risk } \\
\text { (95\% Cl) }\end{array}$ & $P$-value & $\begin{array}{c}\text { Mean } \\
\text { intensity }\end{array}$ & $\begin{array}{c}\text { Relative risk } \\
(95 \% \mathrm{CI})\end{array}$ & $P$-value & $\begin{array}{c}\text { Mean } \\
\text { intensity }\end{array}$ & $\begin{array}{l}\text { Relative risk } \\
\quad(95 \% \mathrm{Cl})\end{array}$ & $P$-value \\
\hline \multicolumn{11}{|c|}{ Combined Gleason grade } \\
\hline 6 & 16 & 0.7 & NA & & 1.88 & NA & & 0.30 & NA & \\
\hline 7 & 14 & 1.51 & NA & & 2.21 & NA & & 1.21 & NA & \\
\hline$\geqslant 8$ & 7 & 1.29 & NA & & 1.99 & NA & & 2.00 & NA & \\
\hline \multicolumn{11}{|c|}{ Extracapsular spread } \\
\hline Positive & 24 & 1.43 & & & 2.13 & & & 1.41 & & \\
\hline Negative & 13 & 0.65 (reference) & $2.07(1.04-4.13)$ & $0.01^{\mathrm{a}}$ & 1.87 (reference) & $1.27(0.76-2.11)$ & $N S^{a}$ & 0.08 (reference) & $2.55(1.39-4.65)$ & $0.0011^{\mathrm{a}}$ \\
\hline \multicolumn{11}{|l|}{ Surgical margins } \\
\hline Positive & 16 & 1.15 & & & 1.84 & & & 1.47 & & \\
\hline Negative & 21 & 1.12 (reference) & $1.15(0.68-3.08)$ & $N S^{a}$ & 2.18 (reference) & $0.7 \mid(0.32-\mid .53)$ & $N S^{a}$ & 0.50 (reference) & $4.75(1.62-13.93)$ & $0.0006^{\mathrm{a}}$ \\
\hline \multicolumn{11}{|c|}{ VEGFR-3+ vessels } \\
\hline Positive & 18 & 1.29 & & & 2.07 & & & 1.53 & & \\
\hline Negative & 19 & 0.97 (reference) & $1.27(0.62-2.60)$ & $N S^{a}$ & 2.00 (reference) & $1.20(0.0-2.39)$ & $\mathrm{NS}^{\mathrm{a}}$ & 0.33 (reference) & $2.85(1.28-6.37)$ & $0.0067^{\mathrm{a}}$ \\
\hline \multicolumn{11}{|c|}{ Lymph node metastasis } \\
\hline Positive & 16 & $|.4|$ & & & 2.06 & & & 1.93 & & \\
\hline Negative & 21 & I.01 (reference) & $1.62(0.67-3.97)$ & $\mathrm{NS}^{\mathrm{a}}$ & 2.00 (reference) & $0.84(0.48-1.46)$ & $N S^{a}$ & 0.15 (reference) & $13.22(1.94-90.00)$ & $<0.0001^{\mathrm{a}}$ \\
\hline
\end{tabular}

Abbreviations: VEGFR = vascular endothelial growth factor receptor; NA = not applicable; NS = not significant; $\mathrm{Cl}=$ confidence interval. ${ }^{\mathrm{a}} \mathrm{Fisher}$ 's exact test.

Table 2 Inhibin A, inhibin B and activin A protein expression in $\mathrm{NHH} \alpha$ clones

\begin{tabular}{|c|c|c|c|c|c|c|}
\hline \multirow[b]{2}{*}{$\begin{array}{l}\text { Cell } \\
\text { lines }\end{array}$} & \multicolumn{3}{|c|}{ Cell lysates } & \multicolumn{3}{|c|}{ Conditioned media } \\
\hline & $\begin{array}{l}\text { Inhibin A } \\
\left(\mathrm{pg} \mathrm{ml}^{-1}\right)\end{array}$ & $\begin{array}{l}\text { Inhibin B } \\
\left(\mathrm{pg} \mathrm{ml}^{-1}\right)\end{array}$ & $\begin{array}{l}\text { Activin A } \\
\left(\mathrm{ng} \mathrm{ml^{-1 }}\right)\end{array}$ & $\begin{array}{l}\text { Inhibin A } \\
\left(\mathrm{pg} \mathrm{ml}^{-1}\right)\end{array}$ & $\begin{array}{l}\text { Inhibin B } \\
\left(\mathrm{pg} \mathrm{ml}^{-1}\right)\end{array}$ & $\begin{array}{l}\text { Activin A } \\
\left(\mathrm{ng} \mathrm{ml}^{-1}\right)\end{array}$ \\
\hline \multicolumn{7}{|l|}{ LNCaP } \\
\hline$L 16^{a}$ & $<10$ & 166.3 & $<0.011$ & $<10$ & $<10$ & $<0.011$ \\
\hline $\mathrm{L} \mid 7^{\mathrm{a}}$ & $<10$ & 137.4 & $<0.011$ & $<10$ & $<10$ & $<0.011$ \\
\hline$L 18^{\mathrm{a}}$ & $<10$ & 118.5 & $<0.011$ & $<10$ & $<10$ & $<0.011$ \\
\hline $\mathrm{LI}^{\mathrm{b}}$ & $<10$ & 433.6 & $<0.011$ & $<10$ & 88 & $<0.011$ \\
\hline$L 5^{\mathrm{b}}$ & $<10$ & 183.8 & $<0.011$ & $<10$ & 24.7 & $<0.011$ \\
\hline$L 8^{b}$ & $<10$ & 308.7 & $<0.011$ & $<10$ & 161.8 & $<0.011$ \\
\hline \multicolumn{7}{|l|}{$P C 3$} \\
\hline $\mathrm{P} 128^{\mathrm{a}}$ & 50.1 & 67.2 & 1.960 & 76 & $<10$ & 8.860 \\
\hline $\mathrm{PI} 29^{\mathrm{a}}$ & 56 & 64.1 & 1.780 & 80.8 & $<10$ & 7.520 \\
\hline $\mathrm{PI} 30^{\mathrm{a}}$ & 48.1 & 73 & 1.720 & 74.6 & $<10$ & 8.820 \\
\hline $\mathrm{P} 20^{\mathrm{b}}$ & 228.1 & 149.7 & 1.280 & 197 & 185 & 7.320 \\
\hline $\mathrm{PlO} 3^{\mathrm{b}}$ & 194.1 & 186 & 1.690 & 132.3 & 226.4 & 9.340 \\
\hline $\mathrm{Pl} 04^{\mathrm{b}}$ & 221.6 & 187.8 & 1.670 & 194.9 & 177.3 & 11.320 \\
\hline
\end{tabular}

${ }^{\mathrm{a}}$ EV-transfected clones. ${ }^{\mathrm{b}} \mathrm{N} \mathrm{NH} \alpha$ over-expressing clones.

PCa. Thus, to elucidate the effect of elevated levels of INH $\alpha$ expression on PCa cells, we stably transfected LNCaP and PC3 cell lines with an expression vector containing an INH $\alpha \mathrm{cDNA}$ or with a control EV and confirmed the expression of the transgene by PCR (Supplementary Figure 1). Expression of dimeric proteins (inhibin A, inhibin B and activin A) was examined by ELISA. Analysis of cell lysates and conditioned media identified an increase in expression of inhibin B, but not inhibin A in INH $\alpha$ transfected LNCaP cells and both inhibin A and inhibin B in the INH $\alpha$-transfected PC3 cell lines (Table 2). There was no change in activin A level in the transfected cells. The expression of INH $\alpha$ protein was also validated by western blot and immunohistochemistry (data not shown). Immunohistochemistry of antibiotic selected clones revealed that the selected $\mathrm{INH} \alpha$-transfected clones were a heterogeneous population of INH $\alpha$-positive and -negative cells. Because primary PCa cells are known for their heterogeneity and the aim of this study was to determine the effect of elevated levels of INH $\alpha$ in cancer, it was concluded the heterogeneous population was not going to bias the outcomes of the functional assays.

\section{Growth characteristics of INH $\alpha$-transfected LNCaP and PC3 clones in vitro}

To evaluate the effect of over-expression of INH $\alpha$ on the growth of LNCaP and PC3 cell lines, we examined the proliferative capacity and motility of the various clones. Direct cell count demonstrated reduced proliferation of $\mathrm{INH} \alpha$ over-expressing LNCaP cells (Figure 2A) and increased proliferation of PC3 cells (Figure 2B) when compared to their respective EV clones in the later stages of the growth curve. Monolayer wound healing assays showed INH $\alpha$ over-expressing LNCaP cells had a reduced rate of wound closure at earlier time points (Figure 2C) whereas INH $\alpha$ over-expressing PC3 cells demonstrated a trend towards increased rate of wound closure (Figure 2D). Because the significant changes in proliferation and motility observed in this study occur at different time points, it suggests that they are independent from each other.

\section{Effect of INH $\alpha$ over-expression on tumour growth and metastasis}

The influence of INH $\alpha$ on tumour growth and metastasis was determined in vivo. The clones were injected at the orthotopic site (prostate) and after 7-9 weeks primary prostate tumours as well as the adjacent lymph nodes were harvested. Primary prostate tumour size was determined and the incidence of lymph node metastasis was scored. Positive immunostaining for human mitochondrial protein confirmed that the primary and secondary tumours originated from intra-prostatic injection of human cells. $\mathrm{INH} \alpha$ immunostaining was used to confirm $\mathrm{INH} \alpha$ expression in tumours (Figure $3 \mathrm{~A}-\mathrm{D}$, left). Immunostaining in the INH $\alpha$ tumours showed that $\mathrm{INH} \alpha$ expression was not uniform within the tumour, which is consistent with a heterogeneous population of INH $\alpha$-positive and -negative cells in the INH $\alpha$-transfected clones 

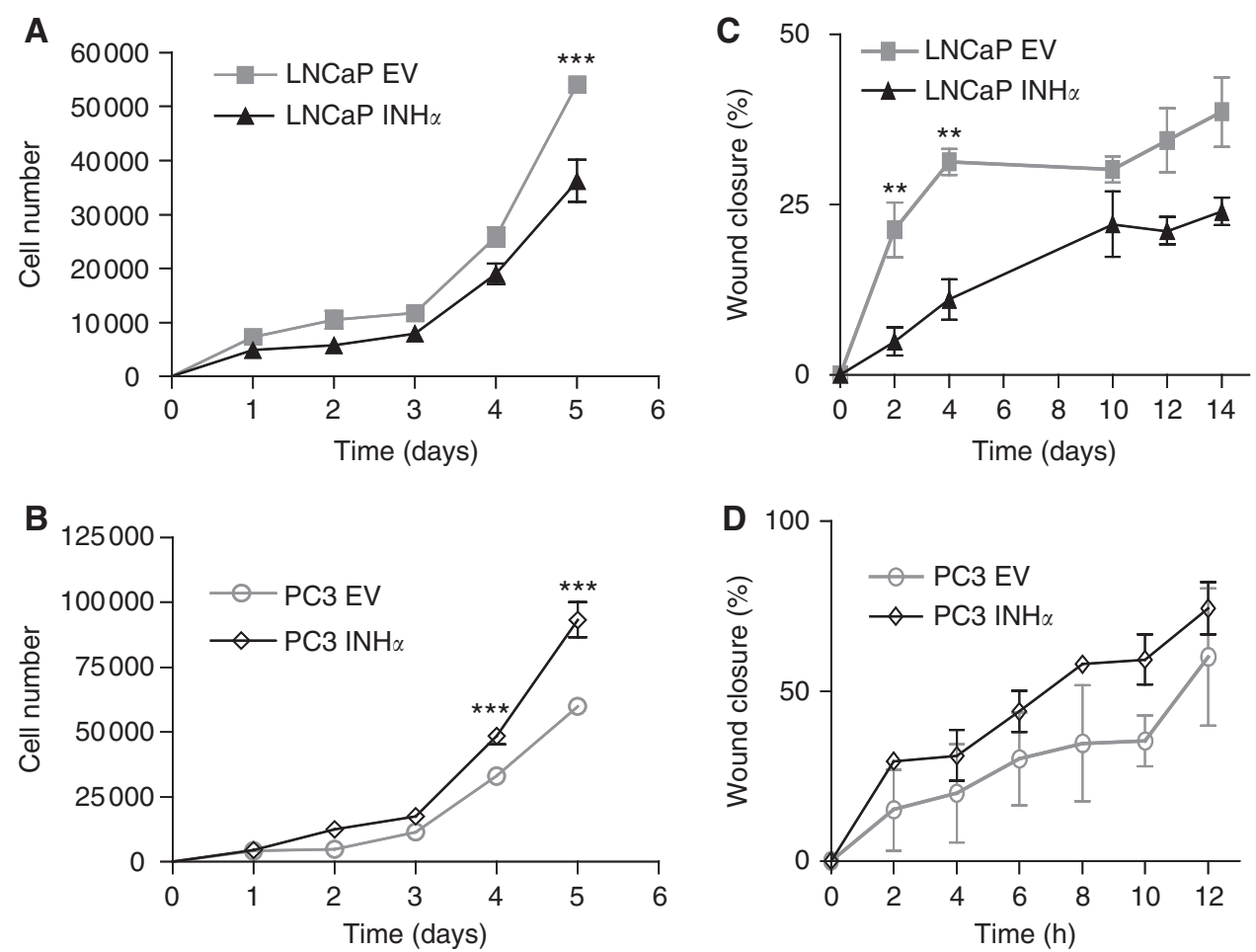

Figure 2 Effect of INH $\alpha$ over-expression on proliferation and motility of LNCaP and PC3 cells, in vitro. (A and $\mathbf{B}$ ) Direct cell counts for EV- and INH $\alpha$ transfected clones are shown; $(\mathbf{C}$ and $\mathbf{D})$ the percentages of wound closure from $\mathrm{EV}$ - and INH $\alpha$-transfected clones are shown. ** $P<0.0 \mathrm{I}$, ****P<0.00I significant difference between the EV- and INH $\alpha$-transfected clones. All results are from representative experiments. Data shown are mean \pm s.e. of the mean.

we had observed previously. INH $\alpha$ immunostaining of the lymph nodes showed INH $\alpha$-positive LNCaP cells to be distributed throughout the lymph node tumours whereas INH $\alpha$-positive PC3 cells were confined to the outer tumour regions (Figure $3 \mathrm{C}$ and $\mathrm{D}$, left). INH $\alpha$ over-expression in LNCaP cells did not affect orthotopic tumour take but significantly reduced the size of the primary tumour $(P=0.0029)$ compared to the EV-transfected clones (Figure $3 \mathrm{~A}$, middle and right). Furthermore, INH $\alpha$ overexpression in $\mathrm{LNCaP}$ cells did not change the incidence of lymph node metastasis or the size of the lymph node tumours (Figure 3C, middle and right). INH $\alpha$ over-expression in PC3 cells had no effect on orthotopic tumour take but a significant increase in the primary prostate tumour size $(P=0.005)$ was observed (Figure $3 \mathrm{~B}$, middle and right). INH $\alpha$ over-expression in PC3 significantly increased the incidence of lymph node tumours $(P=0.0341)$ and lymph node tumour size $(P=0.0047)$ compared to the EVtransfected clones (Figure 3D, middle and right). The altered tumour size following INH $\alpha$ over-expression may have influenced the formation of metastasis.

\section{LVD and invasion of tumour cells into lymphatics in INH $\alpha$ over-expressing primary prostate tumours}

Changes to LVD and lymphangiogenesis are often associated with metastatic spread of cancer cells to the lymph nodes (Mattila et al, 2002; Zeng et al, 2005). To understand the mechanisms and to provide proof of metastatic spread observed in the mice injected with INH $\alpha$-positive cells, we stained LNCaP and PC3 INH $\alpha$ and EV orthotopic tumours for LYVE-1, and human mitochondrial antibody to determine LVD and the degree of invasion of tumour cells into lymphatic vessels (lymphatic invasion) in the tissues. Consistent with our previous study (Zeng et al, 2006), the analysis of LNCaP tumours in the present study was complicated by the significantly larger size of the tumours compared to PC3 tumours.
This larger size resulted in numerous necrotic areas in the LNCaP tumours, making it difficult to consistently define the different tumour peripheries and the intra- and inter-tumoural regions. For this reason stereological analysis of the LNCaP tumours was not possible. However, histological evaluation of the LNCaP tumours demonstrated no LYVE-1-positive lymphatic vessels within the tumour with lymphatic vessels only present in the regions away from the tumour (Figure 4A and B). In contrast, PC3 tumours had lymphatic vessels distributed throughout the tumour (Figure $4 \mathrm{C}$ and D). Stereological analysis of the PC3 tumours revealed a significant increase $(P=0.0023)$ in total LVD in the intra-tumoural regions with no difference in LVD in peritumoural regions and regions away from tumour in INH $\alpha$-positive tumours compared to the controls (Figure 4E). A significant increase in lymphatic invasion in the intra-tumoural $(P=0.0002)$, peritumoural $(P=0.0225)$ and regions away from tumour $(P=0.0077)$ in INH $\alpha$-positive tumour tissues compared to the controls was evident (Figure 4F).

\section{Factors inducing tumour growth and metastasis in INH $\alpha$ over-expressing PC3 tumours}

The observed increase in LVD in INH $\alpha$-positive PC3 tumours suggests that the metastatic spread of the cancer cells from the primary tumour site to the lymph nodes occurs through the process of lymphangiogenesis. Because VEGF-A and VEGF-C have been implicated in inducing/promoting metastasis to the lymph nodes in PCa (Karkkainen et al, 2002; Weis and Cheresh, 2005; Zeng et al, 2006), we went on to determine the expression of VEGF-A and VEGF-C proteins by ELISA (Table 3 ) in INH $\alpha$ - and EV-transfected clones in vitro. There was no significant change in the amount of VEGF-A and VEGF-C secreted by the different LNCaP clones. VEGF-C protein was significantly increased $(P=0.0011)$ in the $\mathrm{INH} \alpha$ over-expressing PC3 clones compared 


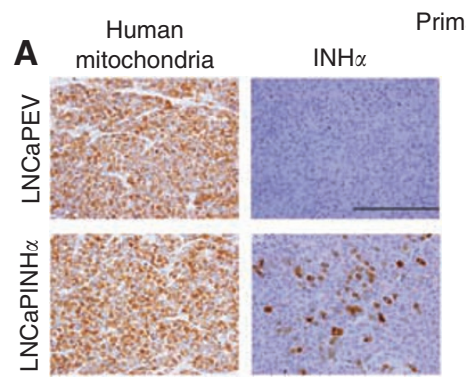

rimary prostate tumour
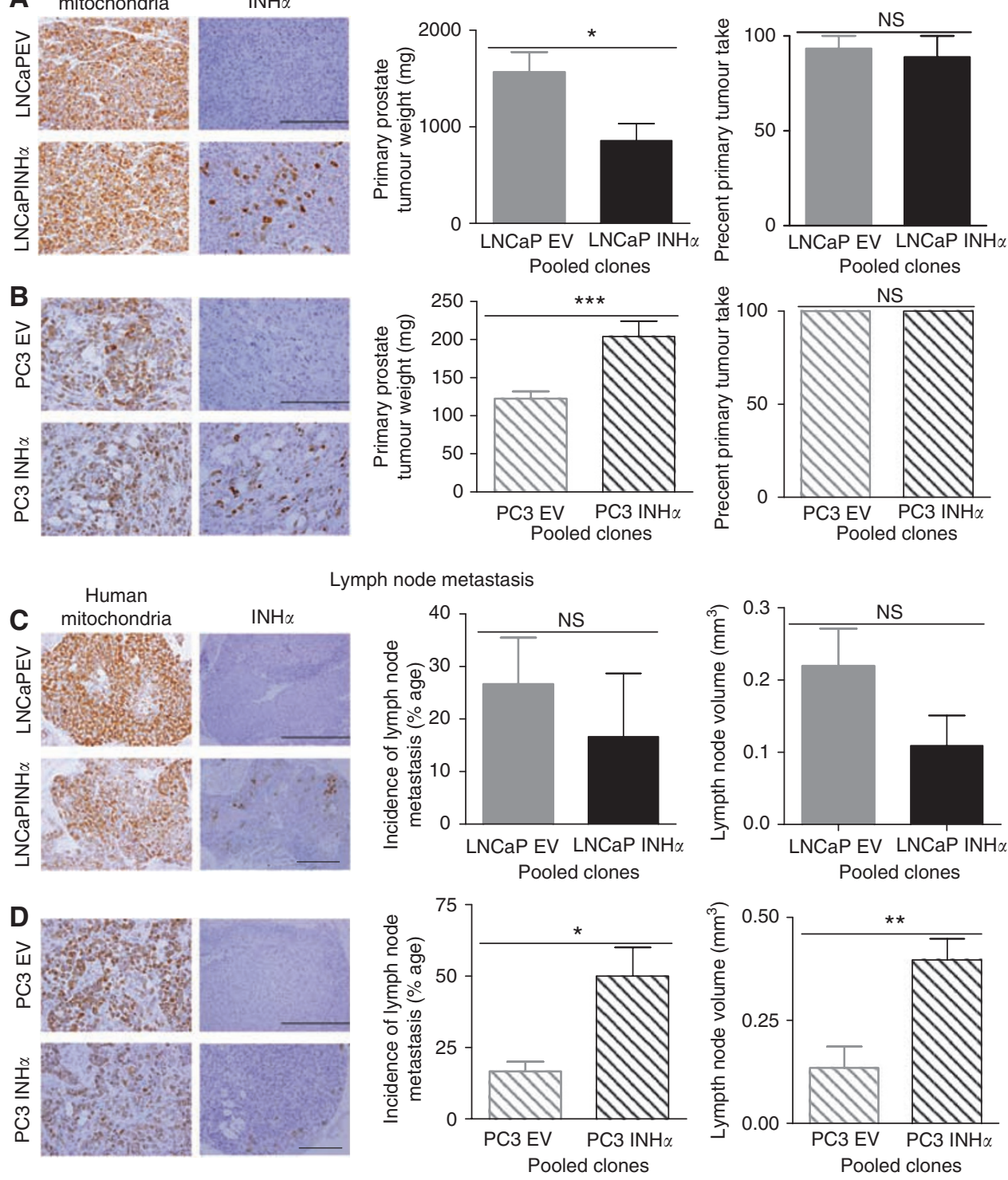

Figure 3 Effect of INH $\alpha$ over-expression on primary prostate tumour growth and lymph node metastasis. (A-D) Left, immunohistochemistry of primary prostate and lymph node tumours using human mitochondria and INH $\alpha$ staining confirmed the human origin of the cells in LNCaP-and PC3-inoculated mice and INH $\alpha$ expression in the tumours. Bar $=200$ and $500 \mu \mathrm{m}$. (A and B) Primary prostate tumour weights (middle) and primary prostate tumour take (right). (C and $\mathbf{D}$ ) Incidence of lymph node metastasis (middle) and lymph node volume (right). $* P<0.05$, $* * P<0.01, * * * P<0.001$ and no significant (NS) difference between the mean of the EV clones and the mean to the INH $\alpha$-transfected clones. The bars represent EV-transfected LNCaP and PC3 clones in grey, INH $\alpha$-transfected LNCaP and PC3 clones in black. Data are shown as mean \pm s.e. of the mean.

to their EV clones, however there was no significant change in secreted VEGF-A levels.

\section{Expression of TGF $\beta$ RIII in LNCaP and PC3 transfected clones}

Although being a receptor for TGF $\beta$, TGF $\beta$ RIII is also a receptor for inhibins (Wiater and Vale, 2003), and recent studies have reported loss of TGF $\beta$ RIII as a common and important event in human PCa (Turley et al, 2007; Sharifi et al, 2007a). Downregulation of TGF $\beta$ RIII in PCa has been suggested to reflect loss of sensitivity to tumour suppressive inhibin by the PCa cells. To test this hypothesis, we determined the levels of TGF $\beta$ RIII mRNA expression in the clones. Consistent with a recent study (Sharifi et al, 2007a), real-time analysis of PCa cell lines revealed LNCaP cells to have more TGF $\beta$ RIII mRNA expression compared to PC3 cells. There was no change in TGF $\beta$ RIII expression in INH $\alpha$ transfected LNCaP or PC3 clones compared to EV-transfected clones (Figure 5).

\section{DISCUSSION}

Although inhibin is used as a biomarker for ovarian cancer, the biological function of elevated levels of $\mathrm{INH} \alpha$ expression in $\mathrm{PCa}$ and certain types of ovarian cancer is unclear. This study is the first functional study to link up-regulation of INH $\alpha$ expression in androgen-independent prostate disease and progression of primary prostate and secondary tumours and metastasis.

We conducted a cross-sectional study to determine a link between INH $\alpha$ expression and a number of clinicopathological parameters: Gleason score, surgical margin status, extracapsular 

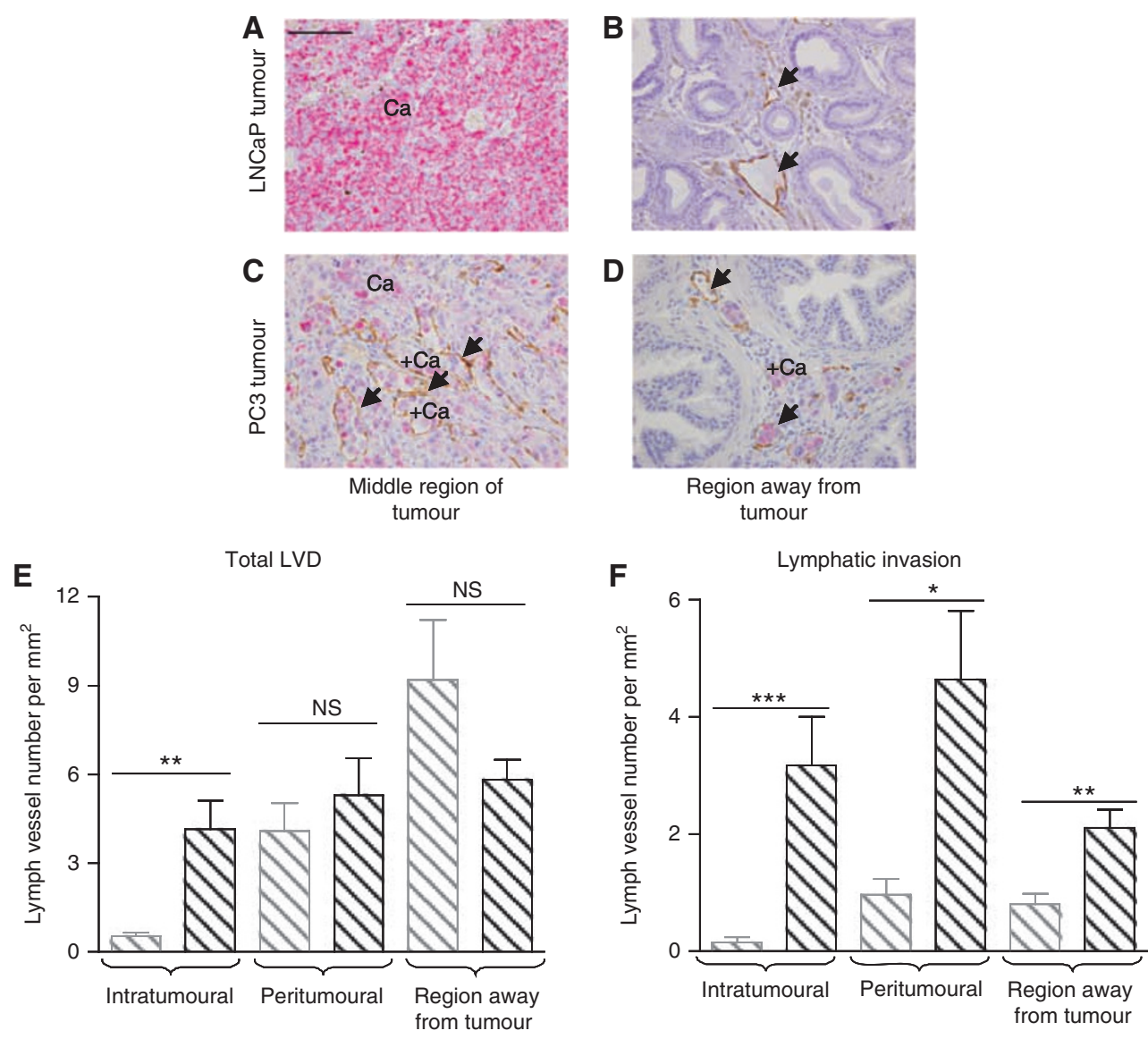

Figure 4 Effect of INH $\alpha$ on lymphatic vessel density and invasion. (A-D) Lymphatic vessels (LVs) were stained with LYVE-I antibody (brown, $\leftarrow)$ and human prostate cells (Ca) with human mitochondria antibody (purple). Bar $=200 \mu \mathrm{m}$. The total number of LVs (E) and LVs with cancer cells in their lumen $(\mathbf{F})$ (for example, of such a vessel see ' + Ca' in panels $\mathbf{C}$ and $\mathbf{D}$ ) in the intra-tumoural, peritumoural and region away from tumour of the primary prostate tumour were counted. $* P<0.05$, *P $<0.01$, ***P $<0.001$ and no significant (NS) difference between LVD in INH $\alpha$ over-expressing primary tumour compared to EV tumours. The bars represent EV-transfected PC3 clones in grey, INH $\alpha$-transfected PC3 clones in black. Data are shown as mean \pm s.e. of the mean.

Table 3 Effect of over-expressing INH $\alpha$ on VEGF-A and VEGF-C expression

\begin{tabular}{|c|c|c|c|c|}
\hline & \multicolumn{2}{|c|}{ LNCaP } & \multicolumn{2}{|c|}{ PC3 } \\
\hline & $\begin{array}{l}\text { EV } \\
\text { clones }\end{array}$ & $\begin{array}{l}\text { INH } \alpha \\
\text { clones }\end{array}$ & $\begin{array}{l}\text { EV } \\
\text { clones }\end{array}$ & $\begin{array}{l}\text { INH } \alpha \\
\text { clones }\end{array}$ \\
\hline $\begin{array}{l}\text { VEGF-A } \\
\text { Secreted } \\
\text { protein }\left(\mathrm{pg} \mathrm{ml}^{-1}\right)\end{array}$ & $|75| \pm 33.48$ & $1747 \pm 26.02$ & $1794 \pm 40.31$ & $1712 \pm 34.64$ \\
\hline $\begin{array}{l}\text { VEGF-C } \\
\text { Secreted } \\
\text { protein }\left(\mathrm{pg} \mathrm{m}{ }^{-1}\right)\end{array}$ & $5.86 \pm 2.66$ & $7.82 \pm 2.13$ & $3377 \pm 566.0$ & $6892 \pm 531.6 * *$ \\
\hline
\end{tabular}

Abbreviations: $\mathrm{EV}=$ empty vector; $\mathrm{VEGF}=$ vascular endothelial growth factor. Data from individual clones were pooled and presented above. $* * P=0.00 \mathrm{I}$.

spread, lymph node status and VEGFR-3 expression, which are well-established prognostic factors of PCa (Wheeler et al, 1998; Cheng et al, 1999, 2001, 2005; Li et al, 2004). This study showed that an elevated level of $\mathrm{INH} \alpha$ expression in the primary prostate tumour can be used as a predictive factor for prognosis in PCa. Univariate analysis showed a significant association between elevated levels of INH $\alpha$ in primary PCa tissues and extracapsular spread, surgical margins, VEGFR-3 expression and lymph node status. This finding is supported by our previous study that reported elevated levels of INH $\alpha$ in PCa patients to be associated with a higher risk of recurrence, although this association was not statistically significant (Risbridger et al, 2004b). The proposed cellular site for $\mathrm{INH} \alpha$ expression and action is epithelial cells, however our immunostaining and analysis of the primary prostate tumour showed a significant association of elevated levels of INH $\alpha$ in both benign epithelial cells and stromal cells to extracapsular spread. There is increasing evidence that the surrounding microenvironment also has a major function in cancer cell growth, survival, invasion and metastatic progression, further supporting the pro-tumourigenic and pro-metastatic function of INH $\alpha$ in advanced PCa (reviewed in Chung et al, 2005; Alberti, 2006; Taylor and Risbridger, 2008). Likewise, Wheeler et al (1998) reported that invasion into or through the capsule of the prostate is strongly associated with both the ability of PCa to metastasise and with recurrence of cancer after radical prostatectomy. Our data link INH $\alpha$ expression in both epithelial and stromal cells with extracapsular spread, which suggests a role for INH $\alpha$ in advanced $\mathrm{PCa}$. In addition, the observed up-regulation of $\mathrm{INH} \alpha$ in benign epithelium and stromal regions in the primary prostate tumours in patients with lymph node metastasis suggests an association with VEGF-C-linked metastasis. Further analysis of our clinical data showed that INH $\alpha$ expression is stronger in benign epithelium and stroma but not the G3/G4 regions of the prostate in patients with lymph node metastasis compared to those with organ-confined 


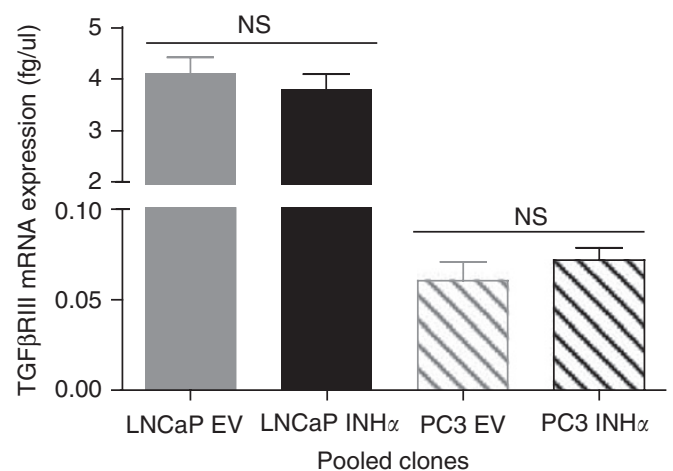

Figure 5 TGF $\beta$ RIII expression in $L N C a P$ and PC3 clones. Total RNA $(2.5 \mu \mathrm{g})$ was reverse transcribed (RT) and absolute quantitative real-time analysis was performed to determine the levels of TGF $\beta$ RIII mRNA expression in the $\mathrm{EV}$ - and $\mathrm{INH} \alpha$-transfected clones. The bars represent $\mathrm{EV}$ transfected LNCaP and PC3 clones in grey, INH $\alpha$-transfected LNCaP and PC3 clones in black. Data are shown as mean \pm s.e. of the mean

disease. In PCa, Tsurusaki et al (1999) found that VEGF-C mRNA levels were significantly higher in lymph-node-positive tumours and that VEGFR-3-positive vessels were increased in the stroma of VEGF-C-positive tumours. Also, VEGF-C has been shown to promote growth of lymphatic vessels into and around tumours in animal models and this was associated with metastatic spread to the lymph nodes and sometimes to distant organs (Mandriota et al, 2001; Skobe et al, 2001; Mattila et al, 2002). Collectively, our analysis of INH $\alpha$ expression in primary prostate tumour tissues and the association to well-established prognostic factors strongly supports a pro-tumourigenic and pro-metastatic function for $\mathrm{INH} \alpha$ in $\mathrm{PCa}$.

Because the proposed cellular site for pro-tumourigenic and pro-metastatic action of INH $\alpha$ is cancer epithelial cells, we overexpressed INHA in metastatic epithelial PCa cell lines, LNCaP and PC3, to evaluate functionally the effect of elevated levels of INH $\alpha$ in $\mathrm{PCa}$. A key event in the progression of PCa is the transition from an androgen-dependent to -independent stage, where subpopulations of tumour cells either gain resistance to, or adapt to, an androgen-depleted environment, and begin to proliferate resulting in the progression to highly aggressive and metastatic androgenindependent disease. Furthermore, when PCa is advanced or metastatic it is usually incurable and tends to metastasise to bone and lymph nodes. LNCaP cells, originally isolated from a lymph node metastasis (Horoszewicz et al, 1980, 1983), have retained their ability to respond to androgens, whereas PC3 cells, originally derived from a bone metastasis (Kaighn et al, 1979), are androgen independent. Thus these cell lines represent early and late stages of metastatic prostate disease.

$\mathrm{INH} \alpha$ over-expression in LNCaP cells demonstrated reduced cell proliferation, migration and primary prostate tumour growth whereas INH $\alpha$ over-expression in these cells did not change the cells' ability to metastasise to the lymph nodes nor did it influence the growth of the lymph node tumours. The lack of change in VEGF-C expression in INH $\alpha$-transfected LNCaP cells is consistent with the unchanged metastatic ability of LNCaP cells in vivo. In contrast, INH $\alpha$ over-expression PC 3 cells demonstrated increased cell proliferation, migration, primary prostate tumour and lymph node tumour growth. These cells showed increased metastasis to the lymph node, which was accompanied by an elevation of LVD and tumour cell invasion into lymphatics. These effects were associated with up-regulation of VEGF-C. Similarly, Karpanen et al (2001) reported that VEGF-C expression in a mouse tumour model strongly promoted the growth of tumourassociated lymphatic vessels, which in the tumour periphery were commonly infiltrated with the tumour cells. Although limited to the use of only two cell lines, the current study is the first to functionally show a pro-tumourigenic and pro-metastatic function for $\mathrm{INH} \alpha$ in an androgen-independent model of metastatic prostate disease.

Another explanation for the different effects of $\mathrm{INH} \alpha$ observed in the current study is the loss or gain of a yet-to-be-identified signalling pathway for $\mathrm{INH} \alpha$ in either tumour suppression or promotion. We have shown that LNCaP cells express more TGF $\beta$ RIII mRNA expression compared to PC3 cells and that the level of TGF $\beta$ RIII mRNA expression is maintained after INH $\alpha$ over-expression. Loss of TGF $\beta$ RIII during PCa progression has been suggested to be a reason for loss of sensitivity to the tumour suppressive effect of inhibin in prostate disease (Turley et al, 2007; Sharifi et al, 2007a,b). Whether androgen status, different cell types and/or levels of TGF $\beta$ RIII expression are responsible for the different effects of inhibin observed in the present study is an important area of future investigation.

Inhibins are known to be involved with regulating members of the $\operatorname{TGF} \beta$ superfamily, including TGF $\beta$ itself, as well as activins and BMP, by competing for their receptors or co-receptors (Wiater and Vale, 2003; Farnworth et al, 2006, 2007). However, unlike other members of the TGF $\beta$ superfamily (Pangas and Woodruff, 2000; Shi and Massagué, 2003), the signalling pathway(s) for inhibin have not yet been defined. Although it remains unclear how INH $\alpha$ mediates downstream cellular events leading to prostate disease, the observed effect of $\mathrm{INH} \alpha$ in the present study suggests and supports an effect of inhibin which is independent of TGF $\beta /$ activin in PCa. Owing to the presence of both $\beta \mathrm{A}$ and $\beta \mathrm{B}$ subunits in $\mathrm{LNCaP}$ and PC3 cells, the clones were able to produce dimeric inhibin $\mathrm{A}$ and inhibin $\mathrm{B}$. The presence of inhibin $\mathrm{B}$ in both LNCaP and PC3 cells is significant as inhibin B is the pre-dominant form of inhibin in men and therefore more relevant to the study of PCa. Although the presence of inhibin A in PC3 may be of relevance to the observed phenotypes of PC3 cells, further investigation into the functional difference resulting from inhibin A vs inhibin B production in these cells was beyond the scope of this project. The level of inhibin A and inhibin B produced by the cells reflects the level of the $\beta$-subunits expressed and secreted by the respective cell lines (McPherson et al, 1999). Our study showed no change in the levels of activin $\mathrm{A}(\beta \mathrm{A} \beta \mathrm{A})$, which indicates that observed effects are specific to inhibin and not a response to activin levels. Therefore, although TGF/ $\beta$ /activins have been shown to induce expression of angiogenic/lymphangiogenic factors through $\mathrm{P} 13 \mathrm{~K}$ and/or SMAD2 pathways (Wagner et al, 2004; Kang, 2006) and TGF $\beta /$ activins inhibit growth of PCa cells (Wilding et al, 1989; Wang et al, 1996; McPherson et al, 1997), the different responses of the PCa cell lines to elevated levels of INH $\alpha$ we have observed cannot be simply explained by abrogation of TGF $\beta$ /activin signalling. Thus, the effect of inhibin on LNCaP cells observed in this study supports a role for inhibin in $\mathrm{PCa}$ independent of TGF $\beta /$ activin. Also, the increased metastatic ability of INH $\alpha$ observed in INH $\alpha$ over-expressing PC 3 cells cannot be due to antagonism of activin action because of the simultaneous expression of follistatin in these cells (McPherson et al, 1999). Follistatin is an activin-binding protein that binds to activin with a high affinity thereby inhibiting activin bioactivity (Phillips and de Kretser, 1998). Taken together, the current study demonstrates a direct action of $\mathrm{INH} \alpha$ in $\mathrm{PCa}$ that is context and/or cell-type dependent.

In summary, this study showed both benign epithelial and stromal regions of primary prostate tumours to be the sites of $\mathrm{INH} \alpha$ expression. We have also demonstrated a strong association of elevated levels of INH $\alpha$ to well-established prognostic factors of PCa. This finding has identified INH $\alpha$ as a very important predictive factor that can be used to identify patients at increased risk for disease progression and cancer death after radical prostatectomy, so that appropriate therapy can be selected. Finally, the current 
study has shown a pro-tumourigenic and pro-metastatic role for $\mathrm{INH} \alpha$ in an androgen-independent model of metastatic prostate disease. This suggests that in the absence of androgens, elevated levels of inhibin may be driving the more aggressive and metastatic phenotypes of PCa tumour.

\section{ACKNOWLEDGEMENTS}

We thank Dr Christopher Bulter for critically reviewing this paper and Dr Stephen McPherson for his assistance with

\section{REFERENCES}

Alberti C (2006) Prostate cancer progression and surrounding microenvironment. Int J Biol Markers 21: 88-95

Balanathan P, Ball EMA, Wang H, Harris SE, Shelling AN, Risbridger GP (2004) Epigenetic regulation of inhibin $\alpha$-subunit gene in prostate cancer cell lines. J Mol Endocrinol 32: 55-67

Ball EM, Mellor SL, Risbridger GP (2004) Cancer progression: is inhibin alpha from Venus or Mars? Cytokine Growth Factor Rev 15: $291-296$

Banerji S, Ni J, Wang SX, Clasperm S, Su J, Tammi R, Jones M, Jackson DG (1999) LYVE-1, a new homologue of the CD44 glycoprotein, is a lymphspecific receptor for hyaluronan. J Cell Biol 144: 789-801

Cheng L, Darson MF, Bergstralh EJ, Slezak J, Myers RP, Bostwick DG (1999) Correlation of margin status and extraprostatic extension with progression of prostate carcinoma. Cancer 86: 1775-1782

Cheng L, Jones TD, Lin H, Eble JN, Zeng G, Carr MD, Koch MO (2005) Lymphovascular invasion is an independent prognostic factor in prostatic adenocarcinoma. J Urol 174: $2181-2185$

Cheng L, Zincke H, Blute ML, Bergstralh EJ, Scherer B, Bostwick DG (2001) Risk of prostate carcinoma death in patients with lymph node metastasis. Cancer 91: 66-73

Chung LW, Baseman A, Assikis V, Zhau HE (2005) Molecular insights into prostate cancer progression: the missing link of tumor microenvironment. J Urol 173: 10-20

Farnworth PG, Wang Y, Escalona R, Leembruggen P, Ooi GT, Findlay JK (2007) Transforming growth factor-beta blocks inhibin binding to different target cell types in a context-dependent manner through dual mechanisms involving betaglycan. Endocrinology 148: 5355-5368

Farnworth P, Stanton P, Wang Y, Escalona R, Findlay J, Ooi G (2006) Inhibins differentially antagonize activin and bone morphogenetic protein action in a mouse adrenocortical cell line. Endocrinology 147: $3462-3471$

Horoszewicz J, Leong S, Chu T, Wajsman Z, Friedman M, Papsidero L, Kim U, Chai L, Kakati S, Arya S, Sandberg A (1980) The LNCaP cell line a new model for studies on human prostatic carcinoma. Prog Clin Biol Res 37: $115-132$

Horoszewicz JS, Leong SS, Kawinski EK, Rosenthal H, Chu TM, Mirand EA, Murphy GP (1983) LNCaP model of human prostatic carcinoma. Cancer Res 43: $1809-1818$

Kaighn ME, Narayan KS, Ohnuki Y, Lechner JF, Jones LW (1979) Establishment and characterization of a human prostatic carcinoma cell line (PC-3). Invest Urol 17: 16-23

Kang Y (2006) Pro-metastasis function of TGFbeta mediated by the Smad pathway. J Cell Biochem 98: 1380-1390

Karkkainen MJ, Makinen T, Alitalo K (2002) Lymphatic endothelium: a new frontier of metastasis research. Nat Cell Biol 4: E2 -E5

Karpanen T, Egeblad M, Karkkainen MJ, Kubo H, Yla-Herttuala S, Jaattela M, Alitalo K (2001) Vascular endothelial growth factor C promotes tumor lymphangiogenesis and intralymphatic tumor growth. Cancer Res 61: $1786-1790$

Lappohn RE, Burger HG, Bouma J, Bangah M, Krans M, de Bruijn HW (1989) Inhibin as a marker for granulosa-cell tumors. N Engl J Med 321: $790-793$

Li R, Younes M, Wheeler TM, Scardino P, Ohori M, Frolov A, Ayala G (2004) Expression of vascular endothelial growth factor receptor-3 (VEGFR-3) in human prostate. Prostate 58: $193-199$

Mandriota SJ, Jussila L, Jeltsch M, Compagni A, Baetens D, Prevo R, Banerji S, Huarte J, Montesano R, Jackson DG, Orci L, Alitalo K, Christofori G, Pepper MS (2001) Vascular endothelial growth factor-C-mediated lymphangiogenesis promotes tumour metastasis. EMBO J 20: 672-682 stereological analysis. Post-doctoral training award by United States Department of Defense (PB), Cancer Council Victoria grant-in-aid (EDW), Cancer Institute of New South Wales (LGH), Senior Research Fellowship from Australian National Health and Medical Research Council (NHMRC) and the Pfizer Foundation (MGA and SAS) and by an NHMRC program grant. Principal Research Fellowship from Australian NHMRC (GPR).

Supplementary Information accompanies the paper on British Journal of Cancer website (http://www.nature.com/bjc)

Marchetti C, Hamdane M, Mitchell V, Mayo K, Devisme L, Rigot JM, Beauvillain JC, Hermand E, Defossez A (2003) Immunolocalization of inhibin and activin alpha and betaB subunits and expression of corresponding messenger RNAs in the human adult testis. Biol Reprod 68: $230-235$

Mattila MM, Ruohola JK, Karpanen T, Jackson DG, Alitalo K, Harkonen PL (2002) VEGF-C induced lymphangiogenesis is associated with lymph node metastasis in orthotopic MCF-7 tumors. Int $J$ Cancer 98: 946-951

Matzuk MM, Finegold MJ, Su JG, Hsueh AJ, Bradley A (1992) Alpha-inhibin is a tumour-suppressor gene with gonadal specificity in mice. Nature 360: $313-319$

McCulloch DR, Opeskin K, Thompson EW, Williams ED (2005) BM18: a novel androgen-dependent human prostate cancer xenograft model derived from a bone metastasis. Prostate 65: 35-43

McPherson S, Wang H, Jones M, Pedersen J, Iismaa T, Wreford N, Simpson E, Risbridger $\mathrm{G}$ (2001) Elevated androgens and prolactin in aromatase deficient (ArKO) mice cause enlargement but not malignancy of the prostate gland. Endocrinology 142: 2458-2467

McPherson SJ, Mellor SL, Wang H, Evans LW, Groome NP, Risbridger GP (1999) Expression of activin A and follistatin core proteins by human prostate tumor cell lines. Endocrinology 140: 5303-5309

McPherson SJ, Thomas TZ, Wang H, Gurusinghe CJ, Risbridger GP (1997) Growth inhibitory response to activin A and B by human prostate tumour cell lines, LNCaP and DU145. J Endocrinol 154: $535-545$

Mellor SL, Richards MG, Pedersen JS, Robertson DM, Risbridger GP (1998) Loss of the expression and localization of inhibin alpha-subunit in high grade prostate cancer. J Clin Endocrinol Metab 83: 969-975

Pangas SA, Woodruff TK (2000) Activin signal transduction pathways. Trends Endocrinol Metab 11: 309-314

Phillips DJ, de Kretser DM (1998) Follistatin: a multifunctional regulatory protein. Front Neuroendocrinol 19: 287-322

Risbridger GP, Ball EM, Wang H, Mellor SL, Peehl DM (2004a) Re-evaluation of inhibin alpha subunit as a tumour suppressor in prostate cancer. Mol Cell Endocrinol 225: 73-76

Risbridger GP, Schmitt JF, Robertson DM (2001) Activins and inhibins in endocrine and other tumors. Endocr Rev 22: 836-858

Risbridger GP, Shibata A, Ferguson KL, Stamey TA, McNeal JE, Peehl DM (2004b) Elevated expression of inhibin alpha in prostate cancer. J Urol 171: $192-196$

Roberts AB, Wakefield LM (2003) The two faces of transforming growth factor beta in carcinogenesis. Proc Natl Acad Sci USA 100: $8621-8623$

Schmitt JF, Millar DS, Pedersen JS, Clark SL, Venter DJ, Frydenberg M, Molloy PL, Risbridger GP (2002) Hypermethylation of the inhibin alpha-subunit gene in prostate carcinoma. Mol Endocrinol 16: 213-220

Sharifi N, Hurt EM, Kawasaki BT, Farrar WL (2007a) TGFBR3 loss and consequences in prostate cancer. Prostate 67: $301-311$

Sharifi N, Lechleider RJ, Farrar WL (2007b) Transforming growth factor-b receptor III downregulation in prostate cancer: is inhibin B a tumor suppressor in prostate? J Mol Endocrinol 39: 329-332

Sharp JA, Waltham M, Williams ED, Henderson MA, Thompson EW (2004) Transfection of MDA-MB-231 human breast carcinoma cells with bone sialoprotein (BSP) stimulates migration and invasion in vitro and growth of primary and secondary tumors in nude mice. Clin Exp Metastasis 21: $19-29$

Shi Y, Massagué J (2003) Mechanisms of TGF-beta signaling from cell membrane to the nucleus. Cell 113: 685-700 
Skobe M, Hamberg LM, Hawighorst T, Schirner M, Wolf GL, Alitalo K, Detmar M (2001) Concurrent induction of lymphangiogenesis, angiogenesis, and macrophage recruitment by vascular endothelial growth factor-C in melanoma. Am J Pathol 159: 893-903

Taylor RA, Risbridger GP (2008) Prostatic tumor stroma: a key player in cancer progression. Curr Cancer Drug Targets 8: 490-497

Tsurusaki T, Kanda S, Sakai H, Kanetake H, Saito Y, Alitalo K, Koji T (1999) Vascular endothelial growth factor-C expression in human prostatic carcinoma and its relationship to lymph node metastasis. Br J Cancer 80: 309-313

Turley RS, Finger EC, Hempel N, How T, Fields TA, Blobe GC (2007) The type III transforming growth factor- $\beta$ receptor as a novel tumor suppressor gene in prostate cancer. Cancer Res 67: $1090-1098$

Wagner K, Peters M, Scholz A, Benckert C, Ruderisch HS, Wiedenmann B, Rosewicz S (2004) Activin A stimulates vascular endothelial growth factor gene transcription in human hepatocellular carcinoma cells. Gastroenterology 126: $1828-1843$

Wang QF, Tilly KI, Tilly JL, Preffer F, Schneyer AL, Crowley Jr WF, Sluss PM (1996) Activin inhibits basal and androgen-stimulated proliferation and induces apoptosis in the human prostatic cancer cell line, LNCaP. Endocrinology 137: 5476-5483

Weis SM, Cheresh DA (2005) Pathophysiological consequences of VEGF-induced vascular permeability. Nat Rev 437: 497-504

Welt CK, Schneyer AL (2001) Differential regulation of inhibin B and inhibin a by follicle-stimulating hormone and local growth factors in human granulosa cells from small antral follicles. J Clin Endocrinol Metab 86: $330-336$

Welt CK, Adams JM, Sluss PM, Hall JE (1999) Inhibin A and inhibin B responses to gonadotropin withdrawal depends on stage of follicle development. J Clin Endocrinol Metab 84: 2163-2169

Wheeler TM, Dillioglugil O, Kattan MW, Arakawa A, Soh S, Suyama K, Ohori M, Scardino PT (1998) Clinical and pathological significance of the level and extent of capsular invasion in clinical stage T1-2 prostate cancer. Hum Pathol 29(8): 856-862

Wiater E, Vale W (2003) Inhibin is an antagonist of bone morphogenetic protein signaling. J Biol Chem 278: 7934-7941

Wilding G, Valverius E, Knabbe C, Gelmann EP (1989) Role of transforming growth factor-alpha in human prostate cancer cell growth. Prostate 15: $1-12$

Zeng Y, Opeskin K, Baldwin ME, Horvath LG, Achen MG, Stacker SA, Sutherland RL, Williams ED (2004) Expression of vascular endothelial growth factor receptor-3 by lymphatic endothelial cells is associated with lymph node metastasis in prostate cancer. Clin Cancer Res 10: $5137-5144$

Zeng Y, Opeskin K, Goad J, Williams ED (2006) Tumor-induced activation of lymphatic endothelial cells via vascular endothelial growth factor receptor-2 is critical for prostate cancer lymphatic metastasis. Cancer Res 66: $9566-9575$

Zeng Y, Opeskin K, Horvath LG, Sutherland RL, Williams ED (2005) Lymphatic vessel density and lymph node metastasis in prostate cancer. Prostate 65: $222-230$ 